\title{
Three-Year Variations in Criteria Atmospheric Pollutants and Their Relationship with Rainwater Chemistry in Karst Urban Region, Southwest China
}

\author{
Jie Zeng ${ }^{1} \oplus$, Xin $\mathrm{Ge}^{2}$, Qixin Wu ${ }^{2, *}$ and Shitong Zhang ${ }^{1}$ \\ 1 Institute of Earth Sciences, China University of Geosciences (Beijing), Beijing 100083, China; \\ zengjie@cugb.edu.cn (J.Z.); stongzhang0103@edu.cn (S.Z.) \\ 2 Key Laboratory of Karst Georesources and Environment, Ministry of Education, \\ College of Resources and Environmental Engineering, Guizhou University, Guiyang 500025, China; \\ april_gexin@163.com \\ * Correspondence: qxwu@gzu.edu.cn
}

Citation: Zeng, J.; Ge, X.; Wu, Q.; Zhang, S. Three-Year Variations in Criteria Atmospheric Pollutants and Their Relationship with Rainwater Chemistry in Karst Urban Region, Southwest China. Atmosphere 2021, 12, 1073. https://doi.org/10.3390/ atmos12081073

Academic Editor: Daniele Contini

Received: 4 July 2021

Accepted: 19 August 2021

Published: 21 August 2021

Publisher's Note: MDPI stays neutral with regard to jurisdictional claims in published maps and institutional affiliations.

Copyright: (c) 2021 by the authors. Licensee MDPI, Basel, Switzerland. This article is an open access article distributed under the terms and conditions of the Creative Commons Attribution (CC BY) license (https:/ / creativecommons.org/licenses/by/ $4.0 /)$.

\begin{abstract}
Air pollutants have been investigated in many studies, but the variations of atmospheric pollutants and their relationship with rainwater chemistry are not well studied. In the present study, the criteria atmospheric pollutants in nine monitoring stations and rainwater chemistry were analyzed in karst Guiyang city, since the time when the Chinese Ambient Air Quality Standards (CAAQS, third revision) were published. Based on the three-year daily concentration dataset of $\mathrm{SO}_{2}$, $\mathrm{NO}_{2}, \mathrm{CO}, \mathrm{PM}_{10}$ and $\mathrm{PM}_{2.5}$, although most of air pollutant concentrations were within the limit of CAAQS III-Grade II standard, the significant spatial variations and relatively heavy pollution were found in downtown Guiyang. Temporally, the average concentrations of almost all air pollutants (except for $\mathrm{CO}$ ) decreased during three years at all stations. Ratios of $\mathrm{PM}_{2.5} / \mathrm{PM}_{10}$ in non- and episode days reflected the different contributions of fine and coarse particles on particulate matter in Guiyang, which was influenced by the potential meteorological factors and source variations. According to the individual air quality index (IAQI), the seasonal variations of air quality level were observed, that is, IAQI values of air pollutants were higher in winter (worst air quality) and lower in summer (best air quality) due to seasonal variations in emission sources. The unique IAQI variations were found during the Chinese Spring Festival. Air pollutant concentrations are also influenced by meteorological parameters, in particular, the rainfall amount. The air pollutants are well scoured by the rainfall process and can significantly affect rainwater chemistry, such as $\mathrm{SO}_{4}{ }^{2-}, \mathrm{NO}_{3}{ }^{-}, \mathrm{Mg}^{2+}$, and $\mathrm{Ca}^{2+}$, which further alters the acidification/alkalization trend of rainwater. The equivalent ratios of rainwater $\mathrm{SO}_{4}{ }^{2-} / \mathrm{NO}_{3}{ }^{-}$and $\mathrm{Mg}^{2+} / \mathrm{Ca}^{2+}$ indicated the significant contribution of fixed emission sources (e.g., coal combustion) and carbonate weathering-influenced particulate matter on rainwater chemistry. These findings provide scientific support for air pollution management and rainwater chemistry-related environmental issues.
\end{abstract}

Keywords: air pollutant; individual air quality index (IAQI); rainwater ion compositions; spatialtemporal variations; karst area

\section{Introduction}

China is a country heavily affected by atmospheric pollution due to rapid socialeconomic development and accelerated urbanization. On the basis of a report from World Health Organization (WHO), up to $80 \%$ of the world's population are exposed to different air pollution degrees [1], especially city dwellers. Millions of people have lost their lives every year due to atmospheric pollution [2]. The two dimensions of atmospheric pollution include the compositions and concentrations of air pollutants (complex mixture). The main contaminants charged into the atmospheric environment are $\mathrm{CO}, \mathrm{SO}_{2}, \mathrm{NO}_{2}, \mathrm{O}_{3}$ and particulate matter (PM, divided into $\mathrm{PM}_{10}$ and $\mathrm{PM}_{2.5}$ by its diameter) $[3,4]$, which could precipitate 
to the earth's surface through atmospheric deposition (especially wet deposition, e.g., acid rain) and further impact the function/structure of the surface ecosystem [5-8]. These air pollutants are also applied in quantifying air contamination levels of the environmental protection administration $[9,10]$.

It is vital to assess air quality, pollutants transport, and the effectiveness of pollutantcutting measures, as they are active responses to the atmospheric pollution. Therefore, the air pollution index (API) of major cities ( 120) in China have been reported by the Ministry of Environmental Protection of China (MEP) since 2000 [10]. The API was calculated on the basis of the daily monitoring concentrations of $\mathrm{NO}_{2}, \mathrm{SO}_{2}$, and $\mathrm{PM}_{10}$ (24 h average). The new prescribed values of $\mathrm{O}_{3}$ and $\mathrm{PM}_{2.5}$ were reported after the publication of the third revision of CAAQS in 2012 [11,12]. Meanwhile, the environmental air quality index (AQI) was also released. The AQI of most cities was analyzed by the observed concentrations of air pollutants $\left(\mathrm{NO}_{2}, \mathrm{SO}_{2}, \mathrm{CO}, \mathrm{O}_{3}, \mathrm{PM}_{2.5}\right.$, and $\left.\mathrm{PM}_{10}\right)$ and opened to the public since 2013. By applying this dataset, the comprehensive spatial-temporal assessments of air quality can be performed, and the relationship between air pollutants and wet deposition (rainfall) can also be explored.

Numerous studies of air pollutants in the developed areas of China have shown that the state of criteria air pollutants (mainly pollution level) is highly heterogeneous on a large scale $[1,3,10,13]$. For instance, the pollutants-based investigation in 15 pilot cities of China showed that the $\mathrm{CO}$ and $\mathrm{SO}_{2}$ concentrations in north China cities were much higher than those in the south, while the difference of $\mathrm{NO}_{2}$ and $\mathrm{O}_{3}$ were not significant [14]. One-year hourly monitoring data of air pollutants in the capital cities of 31 Chinese provinces also highlighted that air pollution can be attributed to multi-pollutants with spatial-temporal variations [3]. The city-scale variations of PM were studied precisely over the Changjiang River Delta and the North China Plain as well [15]. Most surveys focus on large-scale spatial-temporal variations, while the spatial variations and pollution characteristics were rarely reported within the range of a city, in particular, the less developed area in Southwest (SW) China, where the typical continuous karst landforms (e.g., depression and peak cluster) are located in the world [16,17]. There were also few reported studies on individual air quality index (IAQI). Moreover, rainwater is an important sink of air pollutants (both gas and particulate pollutants) [18-20]. Air pollutants could be removed by both in-cloud (dissolution) and below-cloud (scour) processes, which further influenced rainwater chemistry and earth-surface ecosystem $[6,21,22]$. Therefore, the rainwater chemical characteristics are also the reflection of air pollution and air quality. Generally, the rainwater cations are dominantly composed of $\mathrm{Ca}^{2+}, \mathrm{Mg}^{2+}$, and $\mathrm{NH}_{4}{ }^{+}$, while the anions are composed by $\mathrm{SO}_{4}{ }^{2-}$ and $\mathrm{NO}_{3}{ }^{-}[20,23,24]$. The other components, such as metal ions, were negligible (with quite limited concentration compared to the $\mathrm{Ca}^{2+}, 0.1 \sim 1 \%$ [25]. Among them, $\mathrm{NH}_{4}{ }^{+}$ was mainly derived from the $\mathrm{NH}_{3}$ volatilization [26], while $\mathrm{Ca}^{2+}$ and $\mathrm{Mg}^{2+}$ were mainly controlled by dust/particulate dissolution [24]. The $\mathrm{SO}_{4}{ }^{2-}$ and $\mathrm{NO}_{3}{ }^{-}$were originated from atmospheric gas pollutants (precursors) [27,28]. However, the linkage of air pollutants and rainwater chemistry has not been comprehensively studied in karst urban area yet.

To advance further information on variations in atmospheric pollutants and their relation to rainwater chemistry, this study conducted a systematic survey in Guiyang (the most typical karst city of China). Three-year daily concentrations of $\mathrm{SO}_{2}, \mathrm{NO}_{2}, \mathrm{CO}, \mathrm{PM}_{10}$ and $\mathrm{PM}_{2.5}$ of nine ground monitoring sites across the city were investigated, together with the monthly rainwater chemicals. The key objectives of this study are to: (1) clarify the state of criteria air pollutants in a karst city since the third modification of the CAAQS (2012), (2) explore the IAQI-based variations in air pollutants and the potential influencing factors, (3) identify the relationship between atmospheric pollutants and rainwater chemical compositions. 


\section{Methodology}

\subsection{Study Area}

Guiyang City, the capital of Guizhou Province in Southwest China (Figure 1a,b), is one of the three largest global continuous karst areas [29]. The karst landforms are widespread along Guiyang city, and the lithology is controlled by carbonate and clastic rocks. The climate of the study region belongs to subtropical monsoon climate with an annual averaged air temperature of $15.3{ }^{\circ} \mathrm{C}$ and a relative humidity of $77 \%$ [7,30]. Wet season (May to October) commonly represents the time when major rainfall events occurred. The yearly rainfall amount of Guiyang City is $900 \sim 1500 \mathrm{~mm}$ [7]. High population density of more than 4.5 million inhabitants are living in this karst city (550 people per $\mathrm{km}^{2}$, Bureau of Statistics of Guiyang 2013, http:/ / tjj.guiyang.gov.cn/, accessed on 20 April 2018), which are mostly concentrated in the urban region (up to 800 per $\mathrm{km}^{2}$ ). Extensive population leads to the discharge of atmospheric pollutants. The atmospheric $\mathrm{SO}_{2}$ concentration in Guiyang has decreased significantly (3.7 times decrease) since 2003 (Figure 2a) due to the implementation of national/regional environmental protection, such as the National Acid Rain and $\mathrm{SO}_{2}$ Pollution Prevention Plan and Guiyang Blue Sky Project [12,31]. Another target air pollutant in the mitigation policies, $\mathrm{NO}_{2}$ concentration, has gradually increased (Figure 2a) due to the significant rise of motor vehicles number in Guiyang in recent years [31], which results in an increase in the emission of $\mathrm{NO}_{2}$ pollutants. However, compared with the increasing range of vehicle ownership ( 12.6 times), the increasing range of $\mathrm{NO}_{2}$ concentration ( $\sim 1.7$ times) was much smaller. The land use in the study region mainly includes waters, urban area, grass, bareland, farmland, forest, and shrub (Figure 1c).
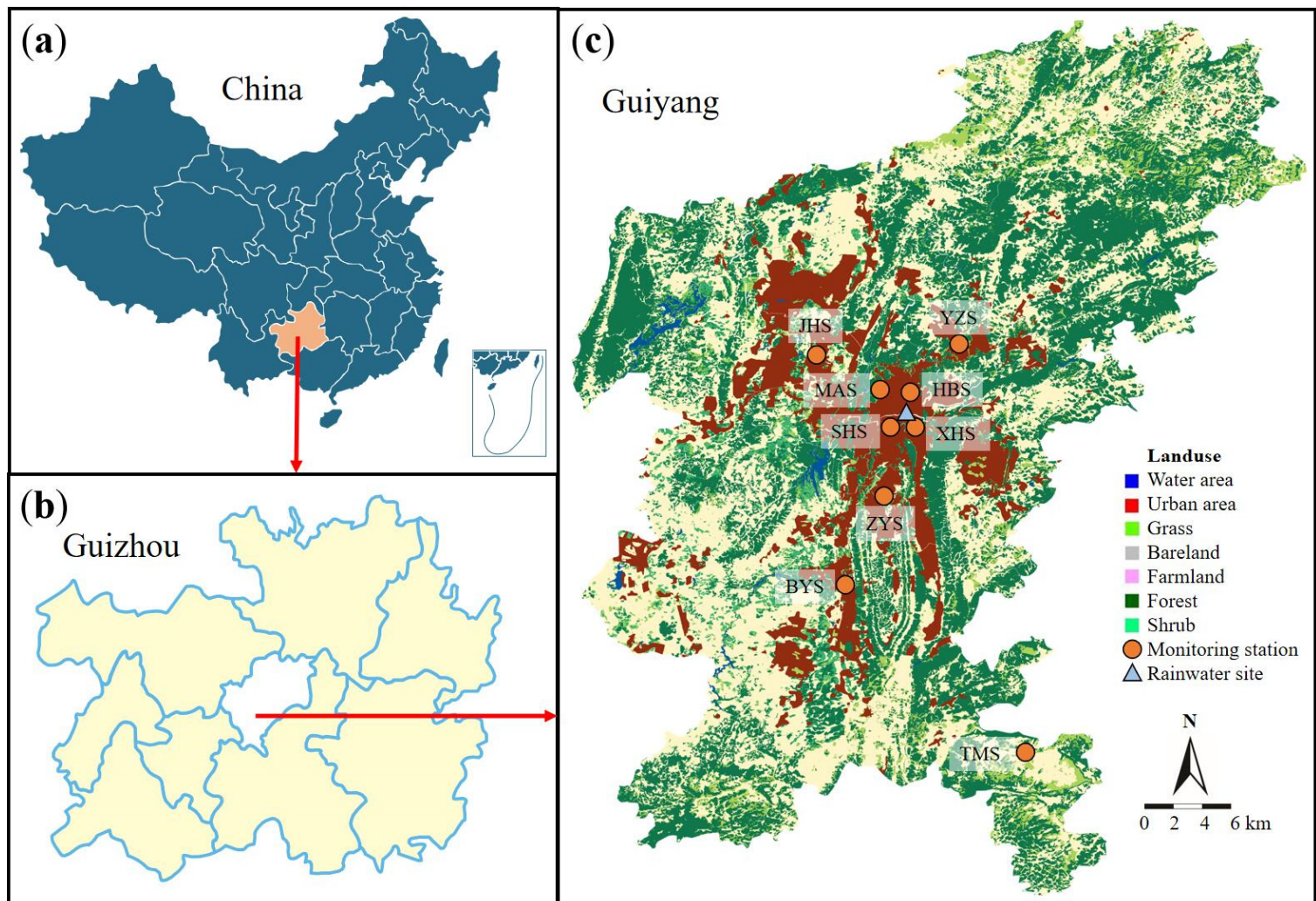

Figure 1. Map of study area. (a) The location of the Guizhou Province; (b) the position of Guiyang city; (c) land use and air quality monitoring stations in Guiyang city. 

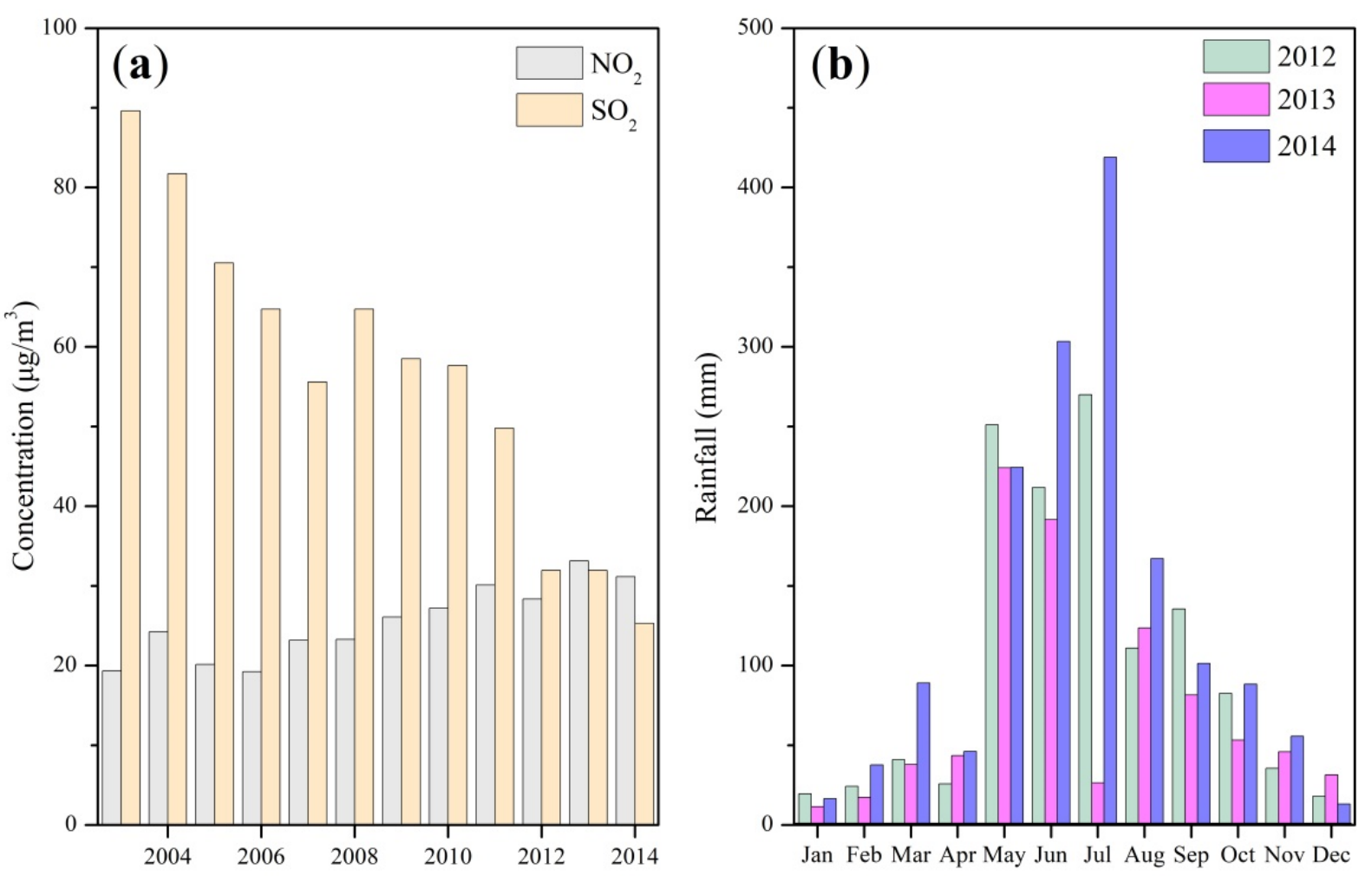

Figure 2. (a) The concentration variations of atmospheric $\mathrm{SO}_{2}$ and $\mathrm{NO}_{2}$ at Guiyang city since 2003 and (b) the monthly rainfall amount in 2012, 2013, and 2014. The data source [27,31].

\subsection{Atmospheric Pollutants Data Collection}

The monitoring air pollutant data of $\mathrm{SO}_{2}, \mathrm{NO}_{2}, \mathrm{PM}_{10}, \mathrm{PM}_{2.5}$, and $\mathrm{CO}$ concentrations (daily mean concentration) were taken from the air quality monitoring stations from 2013 to 2015. A total of eight monitoring stations were selected across downtown Guiyang and one monitoring station is selected in suburb south Guiyang (Tongmuling station). These monitoring stations are distributed from north to south as follows (Figure 1c): Yanzichong station (YZS), Jianhulu station (JHS), Maanshan station (MAS), Hongbianmen station (HBS), Xinhualu station (XHS), Shihuanbaozhan station (SHS), Zhongyuancun station (ZYS), Biyunwo station (BYS), Tongmuling station (TMS). The concentrations of $\mathrm{SO}_{2}, \mathrm{NO}_{2}$, and $\mathrm{CO}$ were measured based on the China Environmental Protection Standards (HJ 193-2013), while that of $\mathrm{PM}_{10}$ and $\mathrm{PM}_{2.5}$ were based on China Environmental Protection Standards (HJ 655-2013).

\subsection{Rainwater Collection and Measurement}

The rainwater sampling was conducted in downtown Guiyang $(26.34$ N, $106.43 \mathrm{E}$, Figure 1c) to well reflect the influence of anthropogenic air pollutants on rainwater in Guiyang city due to its high population density. In brief, rainwater samples were collected by the pre-cleaned polyethylene (PE) sampler set $15 \mathrm{~m}$ above the ground. The rainwater samples after filtration $(0.22 \mu \mathrm{m}$ filters) were sealed in clean PE bottles and kept refrigerated at $4{ }^{\circ} \mathrm{C}$.

According to the corresponding amount in each rainfall event, the collected rainwater samples of each month were proportionally mixed to represent the monthly weightedaverage values [32]. Finally, 18 monthly-mixed samples were obtained between January 2013 and June 2014. It is worth noting that 2013 was an extremely dry year with minimal rainfall in July (Figure $2 b$ ). The monthly-mixed samples were separated into two parts and stored in pre-cleaned PE bottles, respectively. The pre-cleaned procedure of PE bottles can be referred to previous literature [7]. One part was used for the measurement of anions by the ion chromatography (IC, Dionex DX-120), and the concentrations of air 
pollutant-caused rainwater anions (including $\mathrm{NO}_{3}{ }^{-}$and $\mathrm{SO}_{4}{ }^{2-}$ ) were detected. Another part was used for the measurement of cations (acidified by nitric acid, $\mathrm{pH}<2$ ) using the inductively coupled plasma atomic emission spectroscopy (ICP-AES, Thermo Scientific IRIS Intrepid-II), and the rainwater $\mathrm{Ca}^{2+}$ and $\mathrm{Mg}^{2+}$ concentrations were detected. Further details of rainwater ion measurement were reported in previous studies [6,7].

\section{Results and Discussion}

\subsection{Overview of Air Pollutant Concentrations}

\subsubsection{Spatial-Temporal Variations}

The annual mean contents of atmospheric pollutants were measured in all monitoring stations (Figure 3). The annual mean concentrations of $\mathrm{SO}_{2}, \mathrm{NO}_{2}, \mathrm{CO}$, and $\mathrm{PM}_{10}$ were within the CAAQS III-Grade II standard values $\left(60,40,4,70 \mu \mathrm{g} \mathrm{m}^{-3}\right.$ for $\mathrm{SO}_{2}, \mathrm{NO}_{2}, \mathrm{CO}$, $\left.\mathrm{PM}_{10}\right)$, except for the $\mathrm{PM}_{10}$ in $2013\left(81 \mu \mathrm{g} \mathrm{m}^{-3}\right.$, Table S1). The annual mean concentrations of $\mathrm{PM}_{2.5}$ during 2013 to 2015 exceeded the CAAQS III-Grade II standard value (35 $\mu \mathrm{g} \mathrm{m}^{-3}$, Table S1). The annual mean contents of $\mathrm{SO}_{2}$ ranged from $17 \mu \mathrm{g} \mathrm{m}^{-3}$ (MAS) to $50 \mu \mathrm{g} \mathrm{m}^{-3}$ (ZYS) in 2013, from $15 \mu \mathrm{g} \mathrm{m}^{-3}$ (MAS) to $40 \mu \mathrm{g} \mathrm{m}^{-3}$ (ZYS) in 2014, and from $9 \mu \mathrm{g} \mathrm{m}{ }^{-3}$ (MAS) to $24 \mu \mathrm{g} \mathrm{m}^{-3}$ (ZYS) in 2015, respectively. The annual mean contents of $\mathrm{NO}_{2}$ ranged from $17 \mu \mathrm{g} \mathrm{m}^{-3}$ (TMS) to $41 \mu \mathrm{g} \mathrm{m}^{-3}$ (ZYS) in 2013, from $10 \mu \mathrm{g} \mathrm{m}^{-3}$ (TMS) to $40 \mu \mathrm{g} \mathrm{m}^{-3}$ (SHS) in 2014, and from $7 \mu \mathrm{g} \mathrm{m}^{-3}$ (TMS) to $37 \mu \mathrm{g} \mathrm{m}^{-3}$ (SHS) in 2015, respectively. The annual mean concentrations of $\mathrm{CO}$ ranged from $0.51 \mathrm{mg} \mathrm{m}^{-3}$ (TMS) to $0.97 \mathrm{mg} \mathrm{m}^{-3}$ (SHS) in 2013, from $0.53 \mathrm{mg} \mathrm{m}^{-3}$ (TMS) to $1.01 \mathrm{mg} \mathrm{m}^{-3}$ (ZYS) in 2014, and from $0.50 \mathrm{mg} \mathrm{m}^{-3}$ (TMS) to $0.92 \mathrm{mg} / \mathrm{m}^{3}$ (HBS) in 2015, respectively. The annual mean contents of $\mathrm{PM}_{2.5}$ ranged from $35 \mu \mathrm{g} \mathrm{m}^{-3}$ (TMS) to $57 \mu \mathrm{g} \mathrm{m}^{-3}$ (ZYS) in 2013 , from $32 \mu \mathrm{g} \mathrm{m}^{-3}$ (TMS) to $53 \mu \mathrm{g} \mathrm{m}{ }^{-3}$ (ZYS) in 2014, and from $28 \mu \mathrm{g} \mathrm{m}^{-3}$ (TMS) to $44 \mu \mathrm{g} \mathrm{m}^{-3}$ (XHS) in 2015, respectively. The annual mean contents of $\mathrm{PM}_{10}$ ranged from $54 \mu \mathrm{g} \mathrm{m}^{-3}$ (TMS) to $98 \mu \mathrm{g} \mathrm{m}{ }^{-3}$ (YZS) in 2013, from $45 \mu \mathrm{g} \mathrm{m}^{-3}$ (TMS) to $86 \mu \mathrm{g} \mathrm{m}^{-3}$ (SHS) in 2014, and from $39 \mu \mathrm{g} \mathrm{m}^{-3}$ (TMS) to $71 \mu \mathrm{g} \mathrm{m}^{-3}$ (SHS) in 2015, respectively. Obviously, the lowest contents of almost all atmospheric pollutants were collected at the suburban station (TMS, except $\mathrm{SO}_{2}$ ), while the highest contents were found in central urban stations, such as MAS, ZYS, SHS, HBS, and XHS (Figure 3), reflecting the relatively heavy pollution of downtown Guiyang City. It is noteworthy that the annual mean concentration of almost all air pollutants (except for $\mathrm{CO}$ ) showed a decreasing trend from 2013 to 2015 at all stations (Figure 3). The citywide daily average concentrationbased seasonal distribution of the air pollutants are shown in Figure 4. Based on their temporal distributions, the concentrations of all air pollutants presented similar seasonal variations, that is, the lowest and highest concentrations were found in summer and winter, respectively, while the intermediate concentrations were observed in spring and autumn. The variations of anthropogenic emission sources (e.g., coal combustion for heating) and the variations of meteorological factors in different seasons are the main reasons for the seasonal distribution of the air pollutant concentrations $[9,10]$, which will be discussed later. 


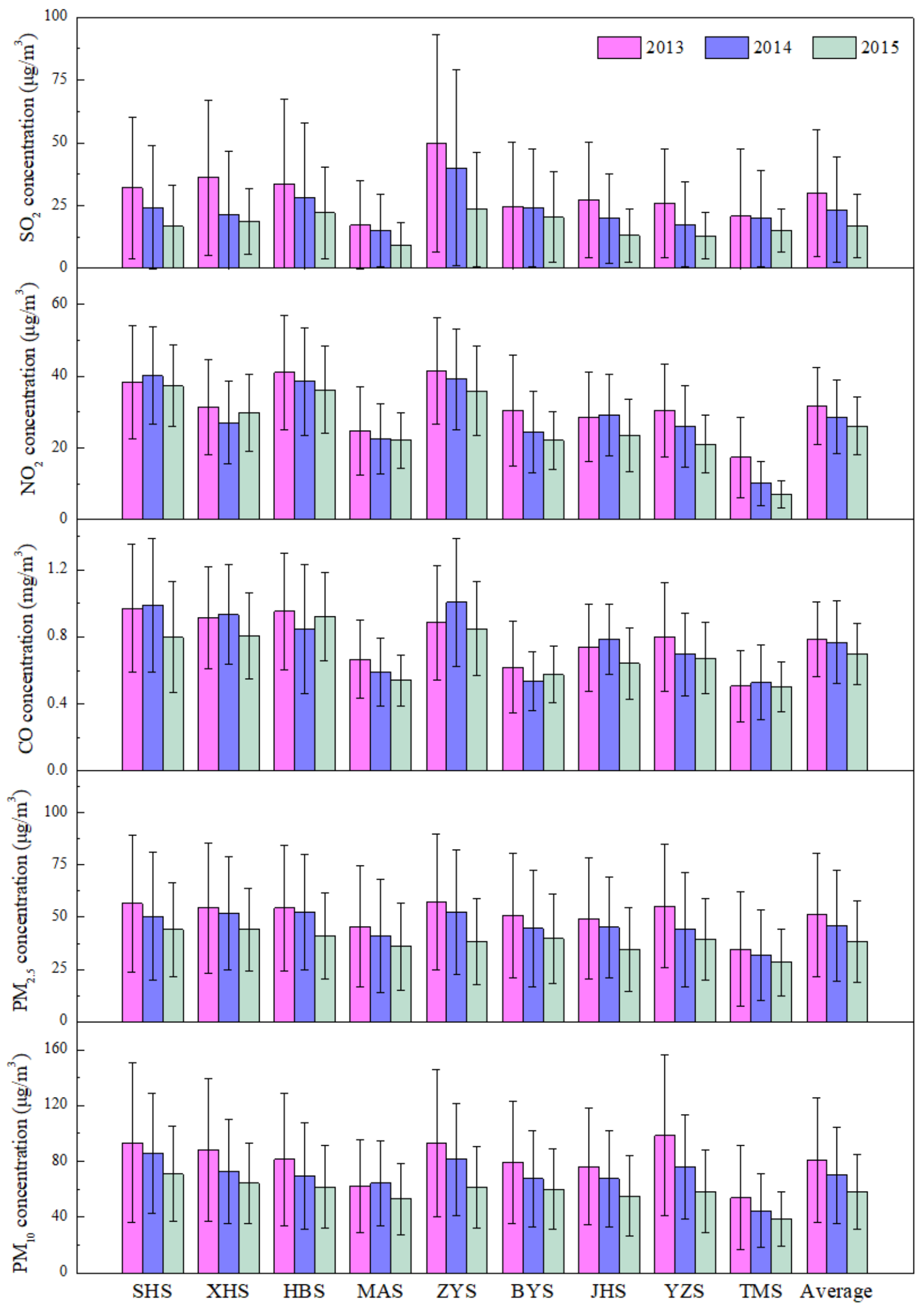

Figure 3. Yearly average concentrations of criteria atmospheric pollutants in Guiyang City from 2013 to 2015. 


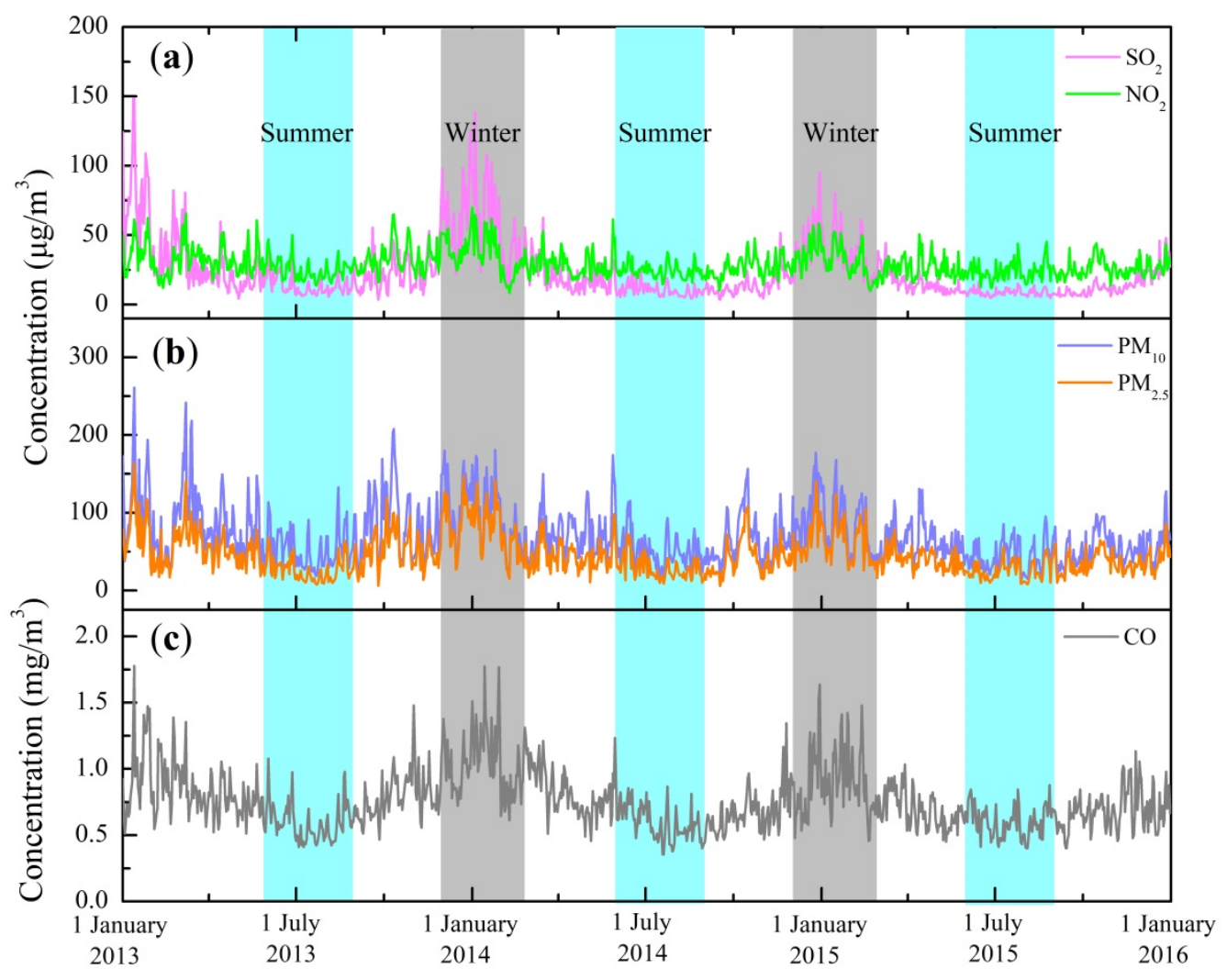

Figure 4. The seasonal variations of citywide daily mean concentrations of air pollutants in Guiyang city from 2013 to 2015. (a) $\mathrm{SO}_{2}$ and $\mathrm{NO}_{2}$, (b) $\mathrm{PM}_{10}$ and $\mathrm{PM}_{2.5}$, (c) CO.

\subsection{2. $\mathrm{PM}_{2.5} / \mathrm{PM}_{10}$ Ratios in Non- and Episode Days}

According to the CAAQS, the episode day represents the day with daily average $\mathrm{PM}_{2.5}$ concentration $>75 \mu \mathrm{g} \mathrm{m}^{-3}$, and the non-episode day is on the contrary $\left(\mathrm{PM}_{2.5}\right.$ concentration $\left.<75 \mu \mathrm{g} \mathrm{m}^{-3}\right)$. Figure 5 presents the ratios of $\mathrm{PM}_{2.5}$ versus $\mathrm{PM}_{10}\left(\mathrm{PM}_{2.5} / \mathrm{PM}_{10}\right)$ during non-episode days and episode days (2013-2015) in all the stations of Guiyang City. The observed mean concentrations of $\mathrm{PM}_{2.5}$ were 93 (TMS) to 101 (SHS) $\mu \mathrm{g} \mathrm{m}{ }^{-3}$ during the episode days, much higher than that in the non-episode days $\left(28 \mu \mathrm{g} \mathrm{m}^{-3}\right.$ of TMS to $41 \mu \mathrm{g} \mathrm{m}^{-3}$ of XHS). Although the numbers of episode days in different stations are comparative, the highest number in episode days was still observed in the background station (TMS). Typically, the mean $\mathrm{PM}_{2.5} / \mathrm{PM}_{10}$ ratios in the SHS station varied between 0.59 on non-episode days and 0.69 on episode days, and in the MAS station between 0.63 on non-episode days and 0.82 on episode days (Figure 5). This phenomenon of the increment indicates that more secondary atmospheric pollutants preferentially tend to formulate $\mathrm{PM}_{2.5}$ (instead of $\mathrm{PM}_{10}$ ) during serious $\mathrm{PM}_{2.5}$ contamination events (episode days) [15,33]. Although relatively higher $\mathrm{PM}_{2.5} / \mathrm{PM}_{10}$ ratios on episode days were observed in all stations compared to the non-episode days (Figure 5), the statistical difference of $\mathrm{PM}_{2.5} / \mathrm{PM}_{10}$ ratios was not exhibited significantly in the non- and episode days (the error bars were overlapped in Figure 5). Overall, the $\mathrm{PM}_{2.5} / \mathrm{PM}_{10}$ ratios in both non- and episode days presented large variations between different stations, suggesting the heterogeneity in $\mathrm{PM}_{10}$ and $\mathrm{PM}_{2.5}$ contamination of different stations. The station with relatively low $\mathrm{PM}_{2.5} / \mathrm{PM}_{10}$ ratios was more likely to reflect the impact of the primary particulate matter on air pollution (more primary particulate matter sources), and further reveal the different efficiency of comprehensive controlling measures of primary and secondary particulate matter. We compared our $\mathrm{PM}_{2.5} / \mathrm{PM}_{10}$ ratios with that monitored in other regions. The mean $\mathrm{PM}_{2.5} / \mathrm{PM}_{10}$ ratio in episode days in Guiyang City (0.73) was generally higher than that in contemporaneous Yangtze River Delta region (0.62 0.66, e.g., Shanghai and Nanjing) 
and much higher than that in the steel industry developed area (0.52, e.g., Shijiazhuang), but was lower than the populous megacity Beijing (0.78) [15], indicating the relatively low contribution of coarse particles on PM during contamination events in Guiyang. This can be explained by the relatively weak migration ability of coarse particles (less affected by wind) and more stringent controls on particle emissions from construction industries (main sources of $\mathrm{PM}_{10}$ ). Moreover, the photochemical processes were likely stronger in higher relative humidity in Guiyang, which were further beneficial to the formation of secondary particulate matter $\left(\mathrm{PM}_{2.5}\right)$ [34], especially in episode days. From the global perspective, the mean $\mathrm{PM}_{2.5} / \mathrm{PM}_{10}$ ratio in non-episode days (0.63) in Guiyang City was comparative to that with similar $\mathrm{PM}_{2.5}$ concentration levels $\left(19 \sim 41 \mu \mathrm{g} / \mathrm{m}^{3}\right)$, such as Hongkong $(0.64$, China), Austria (0.67), Hamilton (0.61, Canada), and Los Angeles (0.61, USA) [35-38].

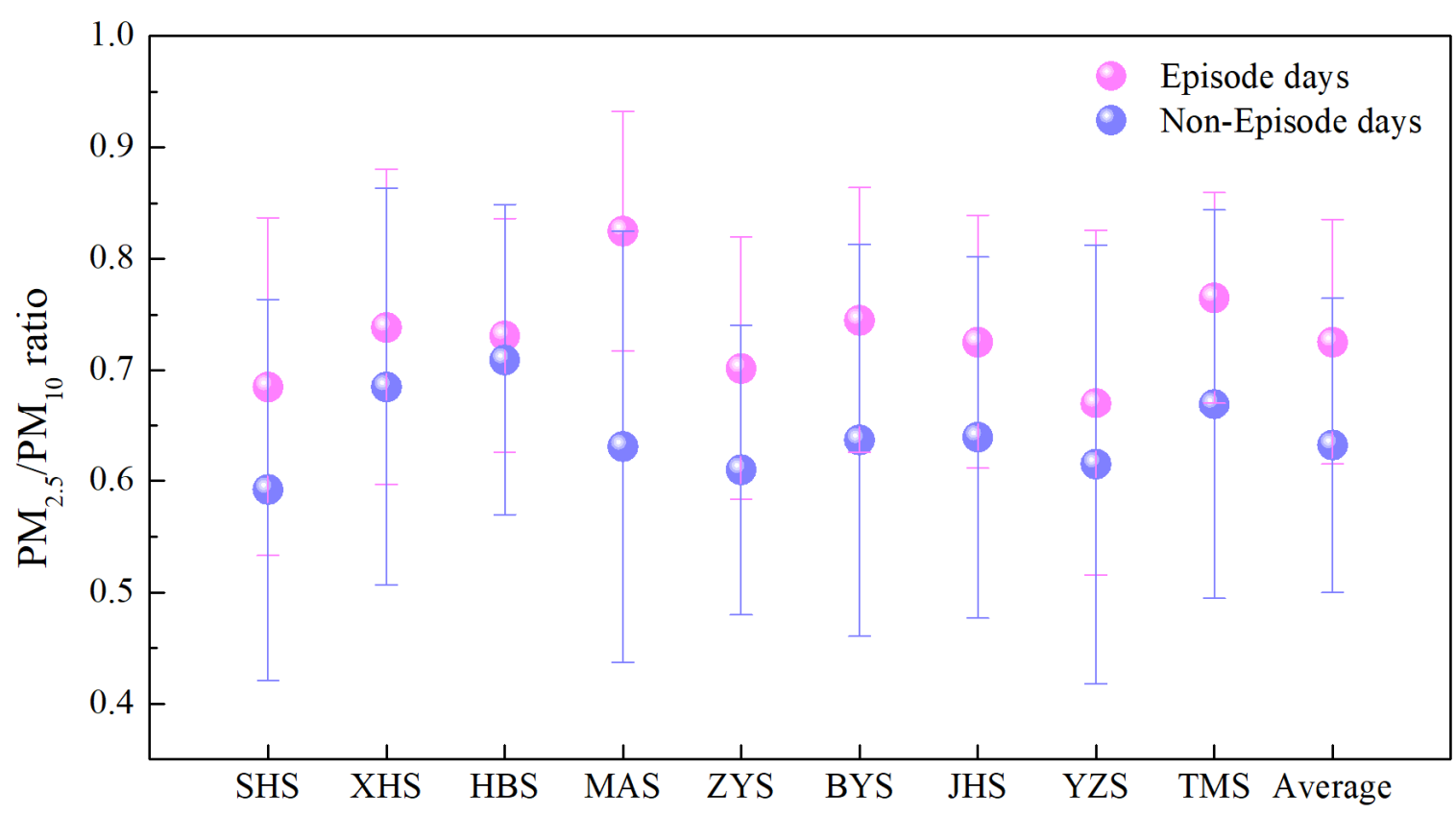

Figure 5. The $\mathrm{PM}_{2.5} / \mathrm{PM}_{10}$ ratios in non- and episode days at all stations in Guiyang City during 2013-2015, the error bars are standard deviations. Shihuanbaozhan station (SHS), Xinhualu station (XHS), Hongbianmen station (HBS), Maanshan station (MAS), Zhongyuancun station (ZYS), Biyunwo station (BYS), Jianhulu station (JHS), Yanzichong station (YZS), Tongmuling station (TMS).

\subsubsection{Correlation among Air Pollutants and Other Meteorological Parameters}

Correlation analysis is a useful tool to explore the sources/processes of air pollutants due to the analogous chemical features and potential co-emission source of the air materials [39,40]. The correlation coefficients between atmospheric pollutants and other meteorological parameters in Guiyang City are calculated and summarized in Table 1. A significant positive correlation $(p<0.01)$ was observed among all air pollutants. $\mathrm{PM}_{2.5}$ was significantly correlated ( $R=0.92$, highest $R$ value) with $P_{10}$ during the study period, indicating the co-emission source or the influence of regional atmospheric conditions on $\mathrm{PM}$ [41], in line with the high ratios of $\mathrm{PM}_{2.5} / \mathrm{PM}_{10}$ (Figure 5). $\mathrm{SO}_{2}$ and $\mathrm{NO}_{2}$ were moderately correlated $(\mathrm{R}=0.67)$, implying the common sources (e.g., fuels-burning) and transformation process (e.g., formation of secondary aerosol). Moreover, $\mathrm{SO}_{2}$ and $\mathrm{NO}_{2}$ were always positively correlated (significant or moderate) with $\mathrm{PM}_{2.5}$ and $\mathrm{PM}_{10}$, reflecting the potential gas-phase oxidation or aqueous reactions of $\mathrm{SO}_{2}$ and $\mathrm{NO}_{2}$, and the furthergenerated nitrate and sulfate (important influence factors on $\mathrm{PM}_{2.5}$ and $\mathrm{PM}_{10}$ ) $[42,43]$. The difference between the $\mathrm{R}$ values of $\mathrm{NO}_{2}$ and $\mathrm{PM}_{10}, \mathrm{SO}_{2}$ and $\mathrm{PM}_{10}$ can be explained by the higher contribution rate of $\mathrm{NO}_{2}$ on secondary aerosol than that of $\mathrm{SO}_{2}$ [10]. 
Table 1. The correlation coefficients on atmospheric pollutants and other meteorological parameters in Guiyang City.

\begin{tabular}{|c|c|c|c|c|c|c|c|c|c|}
\hline & $\mathrm{SO}_{2}$ & $\mathrm{NO}_{2}$ & $\mathrm{PM}_{10}$ & $\mathrm{CO}$ & $\mathbf{P M}_{2.5}$ & RA & AT & WS & $\mathbf{R H}$ \\
\hline $\mathrm{SO}_{2}$ & 1 & & & & & & & & \\
\hline $\mathrm{NO}_{2}$ & $0.67^{* *}$ & 1 & & & & & & & \\
\hline $\mathrm{PM}_{10}$ & $0.68^{* *}$ & $0.81^{* *}$ & 1 & & & & & & \\
\hline $\mathrm{CO}$ & $0.70^{* *}$ & $0.65^{* *}$ & $0.58^{* *}$ & 1 & & & & & \\
\hline $\mathrm{PM}_{2.5}$ & $0.76^{* *}$ & $0.74^{* *}$ & 0.92 ** & $0.68^{* *}$ & 1 & & & & \\
\hline RA & $-0.16^{* *}$ & $-0.10^{* *}$ & $-0.23^{* *}$ & $-0.07^{*}$ & $-0.20^{* *}$ & 1 & & & \\
\hline $\mathrm{AT}$ & $-0.63^{* *}$ & $-0.28^{* *}$ & $-0.25^{* *}$ & $-0.55^{* *}$ & $-0.47^{* *}$ & $0.11^{* *}$ & 1 & & \\
\hline WS & $-0.26^{* *}$ & $-0.46^{* *}$ & $-0.27^{* *}$ & $-0.28^{* *}$ & $-0.25^{* *}$ & -0.04 & $0.09 *$ & 1 & \\
\hline $\mathrm{RH}$ & $-0.20^{* *}$ & $-0.28^{* *}$ & $-0.31^{* *}$ & -0.004 & $-0.17^{* *}$ & $-0.16^{* *}$ & $-0.14^{* *}$ & -0.07 & 1 \\
\hline
\end{tabular}

Notes: ${ }^{* *}$ Correlation is significant at the 0.01 level (two-tailed), ${ }^{*}$ Correlation is significant at the 0.05 level (two-tailed), RA $=$ rainfall amount, $\mathrm{AT}=$ air temperature, $\mathrm{WS}=$ wind speed $(2$ min average $), \mathrm{RH}=$ relative humidity.

In addition, all air pollutants were negatively correlated with rainfall amount (RA), air temperature (AT), wind speed (WS), and relative humidity (RH), reflecting the potential influence of meteorological parameters on air pollution (Table 1). Rainfall process can dilute and remove air pollutants [44], and further lead to the negative correlations between air pollutants and RA, which will be discussed in Section 3.3. As another water-associated meteorological parameter, $\mathrm{RH}$ was also negatively correlated to air pollutants which are similar to RA. This can be explained by the potential dissolution of air pollutants under high RH conditions. High RH could also accelerate the photochemical reaction and result in the transformation of air pollutants [34]. In contrast, the negative correlations were observed between air pollutants and AT. This is because of the increasing requirements of fossil fuel burning (mainly coal combustion) for heating and coal-fired power generation during the cool season (cool half-year), which leads to higher associated pollutant emissions, and vice versa during the warm season (warm half-year). Therefore, the air pollutant concentrations were negatively correlated with AT. The similar negative correlations between temperature and $\mathrm{SO}_{2}$ and $\mathrm{PM}_{10}$ were observed in other areas [45]. A previous study suggested that the long-lived pollutant (e.g., $\mathrm{SO}_{2}$ and $\mathrm{CO}$ ) concentrations were obviously impacted by wind, and further resulted in the regional diffusion/transport of pollutants [46]. The wind field study in Guiyang city also showed that both wind speed and direction conditions were conducive to the production of vertical atmospheric turbulence $[47,48]$, which was beneficial to the diffusion of pollutants. The negative correlations between air pollutants and WS were therefore observed in this study.

\subsection{IAQI-Based Variations of Air Pollutants \\ 3.2.1. Temporal Variations in IAQI}

The air quality of each monitoring station was mainly Grade I and Grade II standard of CAAQS in the study period, and the percentage of the attainment days (better than standard II) increased year by year. In 2015 , the attainment rate was $93.2 \%$, much better than the average level (71.2\%) of 74 monitored cities over China. To further assess the variation of air pollutant, the concentration-based individual air quality index (IAQI) of each pollutant was calculated based on the Technical Regulation on Ambient Air Quality (HJ 633-2012) [10], as follows:

$$
\mathrm{IAQI}=\left[\left(\mathrm{IAQI}_{\mathrm{Hi}}-\mathrm{IAQI}_{\mathrm{Lo}}\right) /\left(\mathrm{BP}_{\mathrm{Hi}}-\mathrm{BP}_{\mathrm{Lo}}\right)\right]\left(\mathrm{C}_{\mathrm{p}}-\mathrm{BP}_{\mathrm{Lo}}\right)+\mathrm{IAQI}_{\mathrm{Lo}}
$$

where IAQI is the individual air quality index, $C_{p}$ is the mass concentration of pollutant $\mathrm{p}, \mathrm{BP}_{\mathrm{Hi}}$ is the high value of corresponding pollutant concentration limits that are close to $\mathrm{C}_{\mathrm{p}}$ in $\mathrm{HJ}$ 633-2012, $\mathrm{BP}_{\mathrm{Lo}}$ is the low value of corresponding pollutant concentration limits 
that are close to $C_{\mathrm{p}}$ in $\mathrm{HJ}$ 633-2012, $\mathrm{IAQI}_{\mathrm{Hi}}$ is the IAQI value corresponding to $\mathrm{BP}_{\mathrm{Hi}}$ in $\mathrm{HJ}$ 633-2012, and $\mathrm{IAQI}_{\mathrm{Lo}}$ is the IAQI value corresponding to $\mathrm{BP}_{\mathrm{Lo}}$ in $\mathrm{HJ}$ 633-2012.

Temporally, the monthly and seasonal mean IAQI values of $\mathrm{SO}_{2}, \mathrm{NO}_{2}, \mathrm{PM}_{10}, \mathrm{PM}_{2.5}$, and $\mathrm{CO}$ varied synchronously; that is, IAQI values of these air pollutants were higher in winter (worst air quality) and lower in summer (best air quality), and those in spring and autumn were in the middle of those in winter and summer (Figure 6). In comparison, the seasonal IAQI variation characteristics of $\mathrm{SO}_{2}$ and $\mathrm{PM}_{2.5}$ were more obvious (Figure $6 \mathrm{a}, \mathrm{d}, \mathrm{f}$ ), while $\mathrm{NO}_{2}, \mathrm{PM}_{10}$, and $\mathrm{CO}$ were relatively insignificant (Figure $6 \mathrm{~b}, \mathrm{c}, \mathrm{e}, \mathrm{f}$ ), indicating the seasonal emission characteristics of $\mathrm{SO}_{2}$ and $\mathrm{PM}_{2.5}$. That is, the $\mathrm{SO}_{2}$ sources were significantly affected by coal-fired heating and power generation in the cool season but not in the warm season, while the $\mathrm{PM}_{2.5}$ sources were mainly controlled by the efficiency of photochemical reactions in different seasons (with different light intensity and temperature) [15]. In contrast, the sources of $\mathrm{NO}_{2}$ and $\mathrm{PM}_{10}$ were mainly controlled by vehicle emissions and construction industry emissions, respectively, and these two sources changed insignificantly in different seasons [32,49].
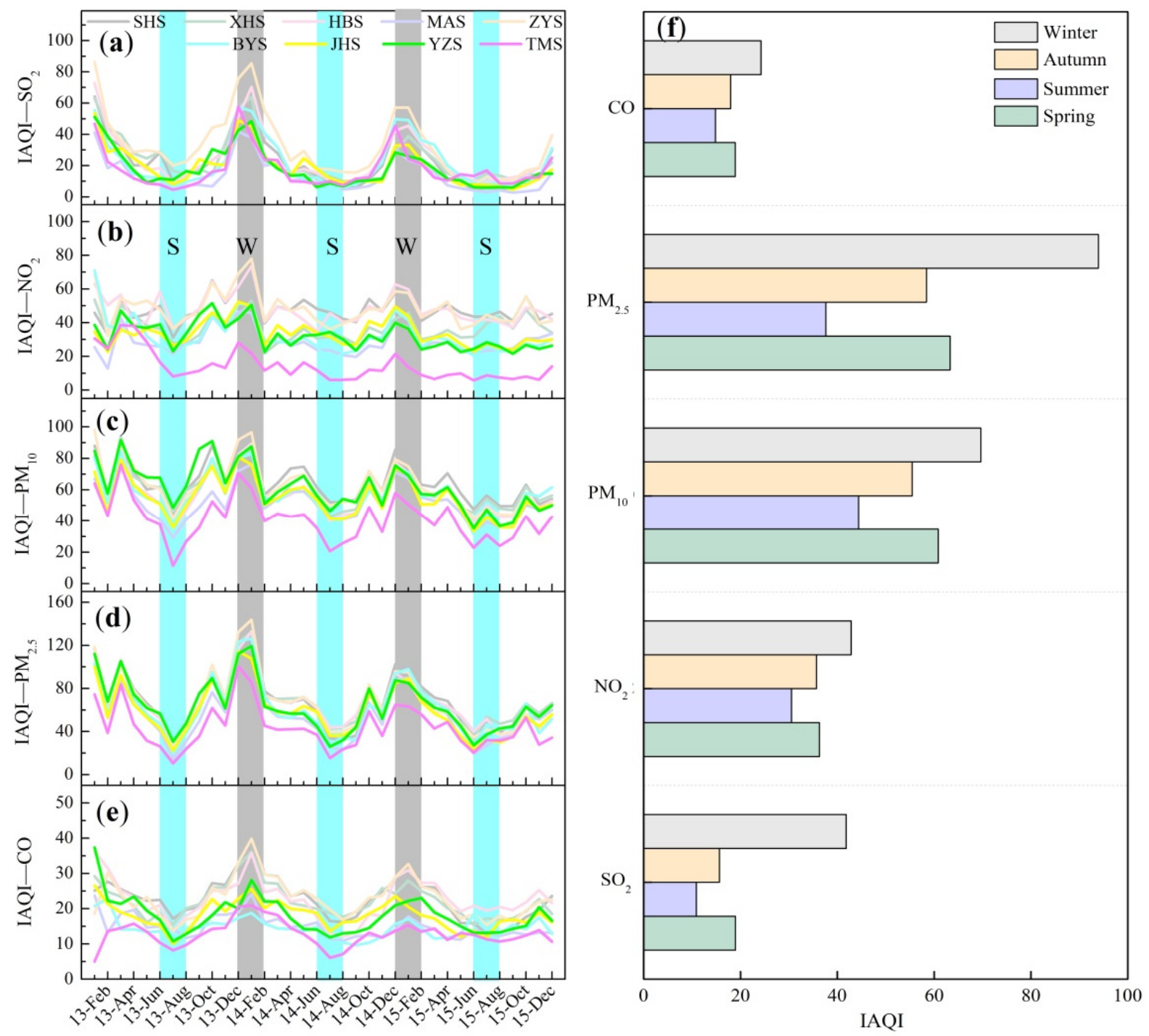

Figure 6. Temporal and seasonal variations in $\mathrm{IAQI}$ of $\mathrm{SO}_{2}, \mathrm{NO}_{2}, \mathrm{PM}_{10}, \mathrm{PM}_{2.5}$, and $\mathrm{CO} ; \mathrm{S}=$ summer, $\mathrm{W}=$ winter. Monthly IAQI values of $\mathrm{SO}_{2}(\mathbf{a}), \mathrm{NO}_{2}(\mathbf{b}), \mathrm{PM}_{10}(\mathbf{c}), \mathrm{PM}_{2.5}(\mathbf{d})$, and $\mathrm{CO}(\mathbf{e})$; Seasonal IAQI values of all air pollutants (f).

The seasonal variations of air pollutants were also observed in Chongqing, another major city in the karst region of SW China, which presents clearer seasonal variation of 
$\mathrm{PM}_{2.5}$ than that of $\mathrm{SO}_{2}$ and $\mathrm{NO}_{2}$ [50]. In megacity Beijing, all gaseous pollutants $\left(\mathrm{SO}_{2}\right.$, $\mathrm{NO}_{2}$, and $\mathrm{CO}$ ) show significant seasonal characteristics, especially $\mathrm{SO}_{2}$ (six-fold difference in concentration in different seasons) [51,52]. The differences of seasonal $\mathrm{SO}_{2}$ variations in Guiyang, Beijing, and Chongqing were observed due to the increasing requirements of fossil fuel burning for heating during the winter in Guiyang and Beijing, but not in Chongqing. However, with the change of air pollution type from soot to mixed type [53,54], the seasonal features of related pollutants may no longer be pronounced.

\subsubsection{Unique IAQI Variations during the Spring Festival}

Air pollutant emissions were significantly influenced by the different intensities of human activities [10,20]. As an important traditional festival in China, the Spring Festival represents a relatively long vacation in winter. During the Spring Festival period (SFP, about half a month vacation), the flow rate of people and vehicles within the city would greatly drop, and the industrial production and construction activities would also be significantly reduced $[55,56]$. All human and industrial activities resume after the vacation. Therefore, the emission characteristics of pollution sources during the SFP were unique. Here, we compared the air pollutant IAQI during the SFP to that in winter and the entire year. As shown in Table 2, all the IAQI IFP /IAQI inter ratios of $\mathrm{SO}_{2}, \mathrm{NO}_{2}, \mathrm{PM}_{10}$, and $\mathrm{PM}_{2.5}$ were smaller than 1 , indicating better air quality during SFP than the winter under similar meteorological conditions. This can also be supported by previous work [57], that is, although the SFP was influenced by the potential fireworks burning [58], the significantly positive impact of emission reduction in industrial and traffic pollution sources on air quality was observed in Guiyang City. It is noteworthy that the IAQI $\mathrm{SFP}_{\mathrm{IAQI}} / \mathrm{I}_{\text {winter }}$ ratios of $\mathrm{PM}_{10}$ and $\mathrm{PM}_{2.5}$ were very close (Table 2), suggesting that the variations in $\mathrm{PM}_{10}$ and $\mathrm{PM}_{2.5}$ were trended to consensus during the whole winter, and the potential sources of these two were similar in Guiyang City. In contrast, the IAQI $\mathrm{SFP}_{\mathrm{SP}} / \mathrm{IAQI}_{\text {yearly }}$ ratios of $\mathrm{PM}_{10}$ and $\mathrm{PM}_{2.5}$ were significantly different (IAQI $\mathrm{SFP}_{\text {/IAQI }}$ yearly ratio of $\mathrm{PM}_{10}$ was always smaller), indicating the influence of varied meteorological factors on air quality in different seasons.

Table 2. The ratios of air pollutant IAQI during the SFP versus the air pollutant IAQI in winter and the entire year.

\begin{tabular}{ccccccccc}
\hline \multirow{2}{*}{ Year } & \multicolumn{3}{c}{ IAQI $_{\mathbf{S F P}} / \mathbf{I A Q I}_{\text {winter }}$} & \multicolumn{4}{c}{ IAQI $_{\mathbf{S F P}} / \mathbf{I A Q I}_{\text {yearly }}$} \\
\cline { 2 - 9 } & $\mathbf{S O}_{\mathbf{2}}$ & $\mathbf{N O}_{\mathbf{2}}$ & $\mathbf{P M}_{\mathbf{1 0}}$ & $\mathbf{P M}_{\mathbf{2 . 5}}$ & $\mathbf{S O}_{\mathbf{2}}$ & $\mathbf{N O}_{\mathbf{2}}$ & $\mathbf{P M}_{\mathbf{1 0}}$ & $\mathbf{P M}_{\mathbf{2 . 5}}$ \\
\hline 2013 & 0.63 & 0.57 & 0.61 & 0.58 & 1.12 & 0.57 & 0.65 & 0.71 \\
\hline 2014 & 0.65 & 0.59 & 0.80 & 0.81 & 1.45 & 0.75 & 1.01 & 1.33 \\
\hline 2015 & 0.58 & 0.51 & 0.69 & 0.69 & 1.28 & 0.64 & 0.92 & 1.10 \\
\hline
\end{tabular}

\subsection{Linkage of Air Pollutants and Rainwater Chemistry}

\subsubsection{Concentration Characteristic of Air Pollutants on Rainy and Non-Rainy Days}

Rainfall process can dilute and remove air pollutants, as confirmed by many studies $[32,44,49]$. Guiyang City has abundant rainfall amount, with nearly half occurred in summer (June to August). As summarized in Table 3, compared to non-rainy days, the air pollutant concentrations (except for $\mathrm{CO}$ ) on rainy days decreased in different degrees, that is, the mean concentrations of $\mathrm{SO}_{2}, \mathrm{NO}_{2}, \mathrm{PM}_{10}$, and $\mathrm{PM}_{2.5}$ on rainy days decreased by $38 \%, 17 \%, 52 \%$, and $32 \%$, respectively. This phenomenon suggested that air pollutants were washed down by rainwater in different degrees, and the removal effect of particulate pollutants was better, especially the larger particle size $\mathrm{PM}_{10}$. Given that the rainfall events generally occurred at night in Guiyang City, the day-night scale rainfall effect on the removal of air pollutants was worth further investigations. The variations in rainwater chemistry of daily-scale continuous observation in Guiyang also supported this finding [59]. 
Table 3. Statistical results of the average contents of air pollutants on rainy and non-rainy days during 2013-2015.

\begin{tabular}{|c|c|c|c|c|c|}
\hline & $\mathrm{SO}_{2}$ & $\mathrm{NO}_{2}$ & $\mathbf{P M}_{10}$ & $\mathrm{CO}$ & $\mathbf{P M}_{2.5}$ \\
\hline & $\mu \mathrm{g} \mathrm{m}^{-3}$ & $\mu \mathrm{g} \mathrm{m}^{-3}$ & $\mu \mathrm{g} \mathrm{m}^{-3}$ & $\mathrm{mg} \mathrm{m}^{-3}$ & $\mu \mathrm{g} \mathrm{m}^{-3}$ \\
\hline Rainy days & 22.2 & 27.5 & 59.1 & 0.8 & 41.4 \\
\hline Non-rainy days & 30.5 & 32.3 & 89.6 & 0.8 & 54.5 \\
\hline Relative difference percentage & $38 \%$ & $17 \%$ & $52 \%$ & - & $32 \%$ \\
\hline
\end{tabular}

\subsubsection{Relationship between Air Pollutants and Rainwater Ions}

The precursor concentration in the ambient air significantly influences the ion concentrations of rainwater [60]. To further explore the relationships between air pollutants and rainwater chemistry, the monthly rainwater ion concentrations $\left(\mathrm{SO}_{4}{ }^{2-}, \mathrm{NO}_{3}{ }^{-}, \mathrm{Mg}^{2+}\right.$, and $\left.\mathrm{Ca}^{2+}\right)$ and atmospheric pollutant concentrations $\left(\mathrm{SO}_{2}, \mathrm{NO}_{2}, \mathrm{PM}_{10}\right.$, and $\left.\mathrm{PM}_{2.5}\right)$ are plotted together in Figure $7 \mathrm{a}-\mathrm{c}$. Overall, the concentrations of rainwater ions and their precursors (atmospheric pollutants, $\mathrm{SO}_{2}$ for $\mathrm{SO}_{4}{ }^{2-}, \mathrm{NO}_{2}$ for $\mathrm{NO}_{3}{ }^{-}, \mathrm{PM}_{10}$ and $\mathrm{PM}_{2.5}$ for $\mathrm{Mg}^{2+}$ and $\left.\mathrm{Ca}^{2+}[18,61,62]\right)$ showed a comparative synchronous variation trend, especially the rainwater $\mathrm{SO}_{4}{ }^{2-}$ and the air $\mathrm{SO}_{2}$ concentrations. Typically, positive correlations were observed between the concentrations of rainwater $\mathrm{SO}_{4}{ }^{2-}$ and air $\mathrm{SO}_{2}(\mathrm{R}=0.76, p<0.05)$, rainwater $\mathrm{NO}_{3}{ }^{-}$and air $\mathrm{NO}_{2}(\mathrm{R}=0.46, p<0.05)$, and rainwater $\left(\mathrm{Mg}^{2+}+\mathrm{Ca}^{2+}\right)$ and $\left(\mathrm{PM}_{10}+\mathrm{PM}_{2.5}\right)$ $(\mathrm{R}=0.52, p<0.05)$. This indicated that the rainfall process can scour the air pollutants well, and the concentrations of gaseous or particulate pollutants in the atmosphere significantly affect the ion compositions of rainwater. Therefore, it alters the neutralization process and acidification/alkalization trend of rainwater, and further influences the earth-surface ecosystem $[6,20]$. The strong or moderate correlation between different rainwater ions and their atmospheric precursors indicates the different dissolving capacity of rainfall washout on different air pollutants, which can be explained by the previous study that focused on the impact of air pollutants on rainwater chemistry [60]. For instance, $\mathrm{SO}_{2}$ dissolves easily in rainwater, but $\mathrm{NO}_{2}$ does not. Therefore, $\mathrm{SO}_{2}$ could be relatively efficient scavenged by rainfall, while $\mathrm{NO}_{2}$ could only dissolve quickly after formed to $\mathrm{HNO}_{3}\left(\mathrm{NO}_{2}\right.$ oxidation by $\mathrm{HO}$ ), which is easily scavenged by rainfall $[60,63]$. The PM-related rainwater chemical study also indicated that the efficiency of the washing process was determined not only by the rainfall amount but also by the kinetic energy of the rainfall event, namely, the combined effects of rainfall amount and intensity $[64,65]$. Nevertheless, as discussed above, the negative correlations were observed between air pollutants and rainfall amount (Table 1); that is, the concentrations of air pollutants were decreased with increasing rainfall amount. However, it is noteworthy that the concentrations of air pollutants no longer decrease significantly with the increase of rainfall amount after reaching a critical point $(\sim 100 \mathrm{~mm}$, the grey box in Figure $7 \mathrm{~d}, \mathrm{e}, \mathrm{f})$, and then stayed at a low concentration level. This can also be supported by previous studies $[30,66]$.

The monthly equivalent ratios of $\mathrm{SO}_{4}{ }^{2-} / \mathrm{NO}_{3}{ }^{-}$and $\mathrm{Mg}^{2+} / \mathrm{Ca}^{2+}$ were also calculated and are plotted in Figures $7 \mathrm{~g}$ and $7 \mathrm{~h}$, respectively, to preliminarily explore the relative contribution of different sources on rainwater $\mathrm{SO}_{4}{ }^{2-}, \mathrm{NO}_{3}{ }^{-}, \mathrm{Mg}^{2+}$, and $\mathrm{Ca}^{2+}$. Generally, the fixed pollution emissions-controlled rainwater presented a $\mathrm{SO}_{4}{ }^{2-} / \mathrm{NO}_{3}{ }^{-}$ ratio much greater than 1 , while the mobile emissions-controlled rainwater showed a $\mathrm{SO}_{4}{ }^{2-} / \mathrm{NO}_{3}{ }^{-}<1[53,67,68]$. All the $\mathrm{SO}_{4}{ }^{2-} / \mathrm{NO}_{3}{ }^{-}$ratios were found $>1$ in Guiyang rainwater (up to 198) (Figure 7g), revealing the significant contribution of fixed emission sources (e.g., coal combustion) on rainwater ions and the limited contribution of mobile emissions (e.g., traffic emission). Moreover, as a typical karst city (carbonate widely distributed), the observed $\mathrm{Mg}^{2+} / \mathrm{Ca}^{2+}$ ratios $(<0.5)$ of Guiyang rainwater in Figure $7 \mathrm{~h}$ were trended to the direction of calcite dissolution, suggesting the significant calcite dissolution contribution of carbonate weathering-influenced $\mathrm{PM}_{10}$ and $\mathrm{PM}_{2.5}$ on rainwater $\mathrm{Mg}^{2+}$ and $\mathrm{Ca}^{2+}[69,70]$. 

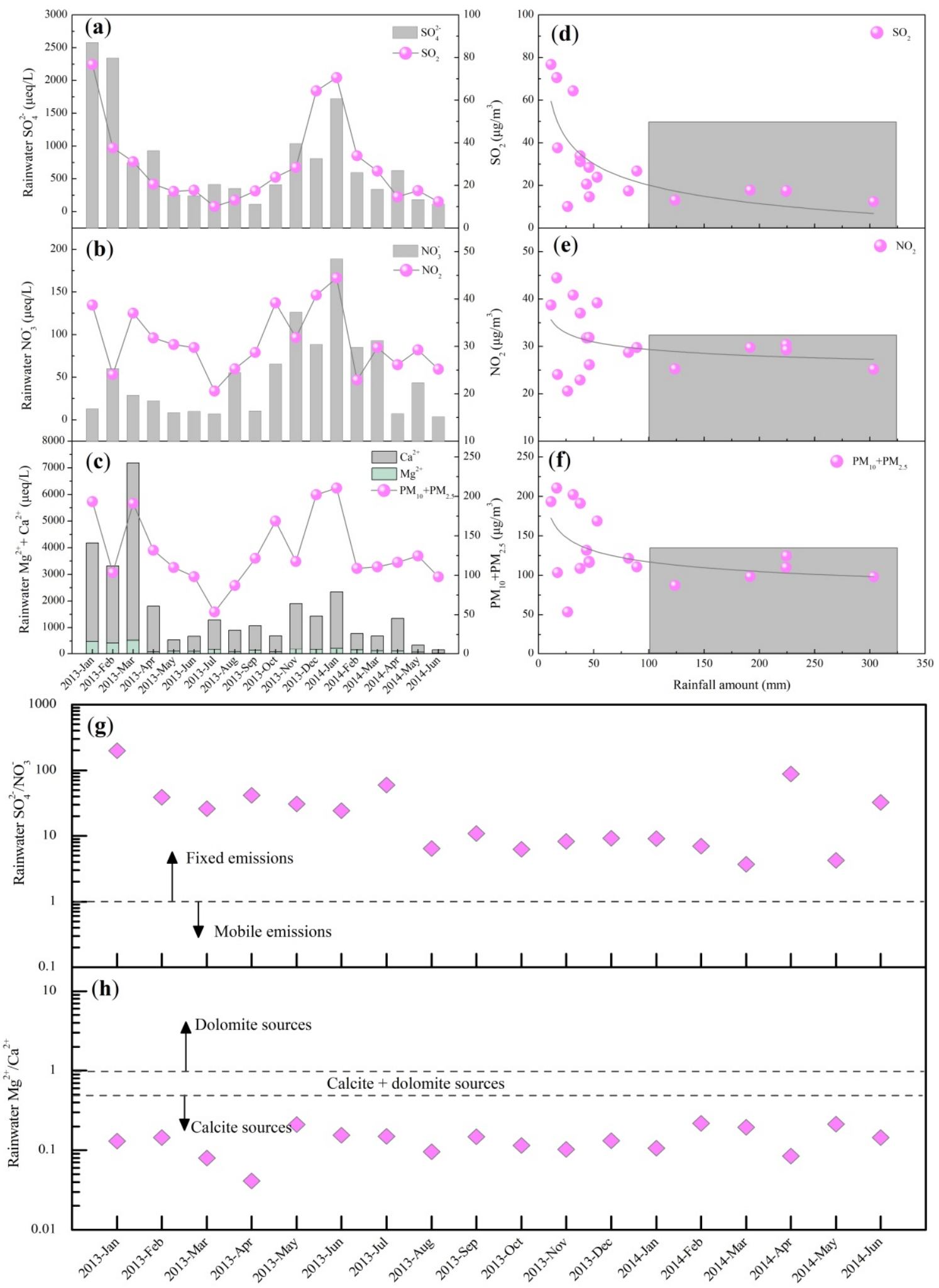

Figure 7. The monthly variations of $\mathrm{SO}_{4}{ }^{2-}, \mathrm{NO}_{3}{ }^{-}, \mathrm{Mg}^{2+}$, and $\mathrm{Ca}^{2+}$ concentrations of rainwater and atmospheric $\mathrm{SO}_{2}, \mathrm{NO}_{2}$, $\mathrm{PM}_{10}+\mathrm{PM}_{2.5}$ concentrations (a-c), the relationships between atmospheric $\mathrm{SO}_{2}, \mathrm{NO}_{2}, \mathrm{PM}_{10}+\mathrm{PM}_{2.5}$ concentrations and rainfall amount $(\mathbf{d}-\mathbf{f})$, the equivalent ratios of rainwater $\mathrm{SO}_{4}{ }^{2-} / \mathrm{NO}_{3}{ }^{-}(\mathbf{g})$ and $\mathrm{Mg}^{2+} / \mathrm{Ca}^{2+}(\mathbf{h})$. The related data sources and reference values are from $[27,61]$. 


\section{Conclusions}

In conclusion, the concentrations of air pollutants $\left(\mathrm{SO}_{2}, \mathrm{NO}_{2}, \mathrm{CO}, \mathrm{PM}_{10}\right.$ and $\left.\mathrm{PM}_{2.5}\right)$ and rainwater chemistry were investigated in a typical karst city (Guiyang, Southwest China). The annual mean concentrations indicated that the $\mathrm{SO}_{2}, \mathrm{NO}_{2}, \mathrm{CO}$, and $\mathrm{PM}_{10}$ were within the CAAQS III-Grade II standard values (except for $\mathrm{PM}_{10}$ in 2013), but $\mathrm{PM}_{2.5}$ exceeded the CAAQS III-Grade II standard value. The relatively heavy pollution was observed in downtown Guiyang. The annual mean concentrations of $\mathrm{SO}_{2}, \mathrm{NO}_{2}, \mathrm{PM}_{10}$ and $\mathrm{PM}_{2.5}$ consistently decreased during the study period. $\mathrm{PM}_{2.5} / \mathrm{PM}_{10}$ ratios revealed that the contribution of coarse particles on PM during the contamination events in Guiyang was relatively low due to the potential meteorological factors and source variations. Seasonal variations of air quality level were observed by calculating the IAQI, which presented the worst air quality in winter and the best in summer attributing to seasonal difference of emission sources. Moreover, the unique IAQI variations were found during the Chinese Spring Festival. The linkage between air pollutants and rainwater chemistry revealed that the rainfall process controlled the concentrations of rainwater ions $\left(\mathrm{SO}_{4}{ }^{2-}, \mathrm{NO}_{3}{ }^{-}, \mathrm{Mg}^{2+}\right.$, and $\mathrm{Ca}^{2+}$ ) and the related rainwater acidification/alkalization. The equivalent ratios of $\mathrm{SO}_{4}{ }^{2-} / \mathrm{NO}_{3}{ }^{-}$and $\mathrm{Mg}^{2+} / \mathrm{Ca}^{2+}$ of rainwater further implied the important contribution of fixed emission sources and weathering-derived particulate matter. This study provides insights into the variations of air pollutants and their linkage to rainwater chemistry in a karst city, and also helps to understand the significance of atmospheric pollution management.

Supplementary Materials: The following are available online at https:/ /www.mdpi.com/article/ 10.3390/atmos12081073/s1, Table S1: The annual mean contents of atmospheric pollutants and the Grade II standard values of CAAQS II and CAAQS III.

Author Contributions: Conceptualization, Q.W. and J.Z.; methodology, J.Z., Q.W. and X.G.; software, J.Z.; validation, Q.W.; formal analysis, J.Z., X.G., Q.W. and S.Z.; investigation, Q.W.; resources, Q.W.; writing — original draft preparation, J.Z., X.G., Q.W. and S.Z.; writing—review and editing, J.Z. and Q.W.; supervision, Q.W.; project administration, Q.W.; funding acquisition, Q.W. All authors have read and agreed to the published version of the manuscript.

Funding: This research was funded by the Joint Fund of the National Natural Science Foundation of China and Guizhou Province, China (U1612442), the National Natural Science Foundation of China (41863004, 41863003, 41763019), and the Guizhou Science and Technology Support Program ([2019]2832). The funders declared no role in study design, data collection and analysis, decision to publish, or preparation of the manuscript.

Institutional Review Board Statement: Not applicable.

Informed Consent Statement: Not applicable.

Data Availability Statement: The data presented in this study are available on request from the corresponding author.

Conflicts of Interest: The authors declare no conflict of interest.

\section{References}

1. Wei, J.; Li, Z.; Guo, J.; Sun, L.; Huang, W.; Xue, W.; Fan, T.; Cribb, M. Satellite-Derived 1-km-Resolution PM1 Concentrations from 2014 to 2018 across China. Environ. Sci. Technol. 2019, 53, 13265-13274. [CrossRef]

2. Chen, Z.; Wang, J.N.; Ma, G.X.; Zhang, Y.S. China tackles the health effects of air pollution. Lancet 2013, 382, 1959-1960. [CrossRef]

3. Wang, Y.; Ying, Q.; Hu, J.; Zhang, H. Spatial and temporal variations of six criteria air pollutants in 31 provincial capital cities in China during 2013-2014. Environ. Int. 2014, 73, 413-422. [CrossRef] [PubMed]

4. Hu, J.; Ying, Q.; Wang, Y.; Zhang, H. Characterizing multi-pollutant air pollution in China: Comparison of three air quality indices. Environ. Int. 2015, 84, 17-25. [CrossRef] [PubMed]

5. Galloway, J.N. Acid deposition: Perspectives in time and space. Water Air Soil Pollut. 1995, 85, 15-24. [CrossRef]

6. Zeng, J.; Yue, F.-J.; Li, S.-L.; Wang, Z.-J.; Wu, Q.; Qin, C.-Q.; Yan, Z.-L. Determining rainwater chemistry to reveal alkaline rain trend in Southwest China: Evidence from a frequent-rainy karst area with extensive agricultural production. Environ. Pollut. 2020, 266, 115166. [CrossRef]

7. Han, G.; Song, Z.; Tang, Y.; Wu, Q.; Wang, Z. Ca and Sr isotope compositions of rainwater from Guiyang city, Southwest China: Implication for the sources of atmospheric aerosols and their seasonal variations. Atmos. Environ. 2019, 214, 116854. [CrossRef] 
8. Wu, Q.; Han, G.; Tao, F.; Tang, Y. Chemical composition of rainwater in a karstic agricultural area, Southwest China: The impact of urbanization. Atmos. Res. 2012, 111, 71-78. [CrossRef]

9. Gurjar, B.R.; Butler, T.M.; Lawrence, M.G.; Lelieveld, J. Evaluation of emissions and air quality in megacities. Atmos. Environ. 2008, 42, 1593-1606. [CrossRef]

10. Xu, Y.; Ying, Q.; Hu, J.; Gao, Y.; Yang, Y.; Wang, D.; Zhang, H. Spatial and temporal variations in criteria air pollutants in three typical terrain regions in Shaanxi, China, during 2015. Air Qual. Atmos. Health 2018, 11, 95-109. [CrossRef]

11. Wen, Z.; Xu, W.; Li, Q.; Han, M.; Tang, A.; Zhang, Y.; Luo, X.; Shen, J.; Wang, W.; Li, K.; et al. Changes of nitrogen deposition in China from 1980 to 2018. Environ. Int. 2020, 144, 106022. [CrossRef]

12. Yu, G.; Jia, Y.; He, N.; Zhu, J.; Chen, Z.; Wang, Q.; Piao, S.; Liu, X.; He, H.; Guo, X.; et al. Stabilization of atmospheric nitrogen deposition in China over the past decade. Nat. Geosci. 2019, 12, 424-429. [CrossRef]

13. Wei, J.; Li, Z.; Cribb, M.; Huang, W.; Xue, W.; Sun, L.; Guo, J.; Peng, Y.; Li, J.; Lyapustin, A.; et al. Improved 1 km resolution PM2.5 estimates across China using enhanced space-time extremely randomized trees. Atmos. Chem. Phys. 2020, 20, 3273-3289. [CrossRef]

14. Chai, F.; Gao, J.; Chen, Z.; Wang, S.; Zhang, Y.; Zhang, J.; Zhang, H.; Yun, Y.; Ren, C. Spatial and temporal variation of particulate matter and gaseous pollutants in 26 cities in China. J. Environ. Sci. 2014, 26, 75-82. [CrossRef]

15. Hu, J.; Wang, Y.; Ying, Q.; Zhang, H. Spatial and temporal variability of PM2.5 and PM10 over the North China Plain and the Yangtze River Delta, China. Atmos. Environ. 2014, 95, 598-609. [CrossRef]

16. Han, G.; Tang, Y.; Liu, M.; Van Zwieten, L.; Yang, X.; Yu, C.; Wang, H.; Song, Z. Carbon-nitrogen isotope coupling of soil organic matter in a karst region under land use change, Southwest China. Agric. Ecosyst. Environ. 2020, 301, 107027. [CrossRef]

17. Liu, M.; Han, G.; Zhang, Q. Effects of agricultural abandonment on soil aggregation, soil organic carbon storage and stabilization: Results from observation in a small karst catchment, Southwest China. Agric. Ecosyst. Environ. 2020, 288, 106719. [CrossRef]

18. Baker, K.; Scheff, P. Photochemical model performance for PM2.5 sulfate, nitrate, ammonium, and precursor $\mathrm{species}^{\mathrm{SO}} \mathrm{SONO}_{3}$, and $\mathrm{NH}_{3}$ at background monitor locations in the central and eastern United States. Atmos. Environ. 2007, 41, 6185-6195. [CrossRef]

19. Szép, R.; Mateescu, E.; Niță, I.-A.; Birsan, M.-V.; Bodor, Z.; Keresztesi, Á. Effects of the Eastern Carpathians on atmospheric circulations and precipitation chemistry from 2006 to 2016 at four monitoring stations (Eastern Carpathians, Romania). Atmos. Res. 2018, 214, 311-328. [CrossRef]

20. Keresztesi, Á.; Birsan, M.-V.; Nita, I.-A.; Bodor, Z.; Szép, R. Assessing the neutralisation, wet deposition and source contributions of the precipitation chemistry over Europe during 2000-2017. Environ. Sci. Eur. 2019, 31, 50. [CrossRef]

21. Larssen, T.; Lydersen, E.; Tang, D.; He, Y.; Gao, J.; Liu, H.; Duan, L.; Seip, H.M.; Vogt, R.D.; Mulder, J.; et al. Acid Rain in China. Environ. Sci. Technol. 2006, 40, 418-425. [CrossRef]

22. Zhou, X.; Xu, Z.; Liu, W.; Wu, Y.; Zhao, T.; Jiang, H.; Zhang, X.; Zhang, J.; Zhou, L.; Wang, Y. Chemical composition of precipitation in Shenzhen, a coastal mega-city in South China: Influence of urbanization and anthropogenic activities on acidity and ionic composition. Sci. Total Environ. 2019, 662, 218-226. [CrossRef] [PubMed]

23. Han, G.; Tang, Y.; Wu, Q.; Tan, Q. Chemical and strontium isotope characterization of rainwater in karst virgin forest, Southwest China. Atmos. Environ. 2010, 44, 174-181. [CrossRef]

24. Xu, Z.; Han, G. Chemical and strontium isotope characterization of rainwater in Beijing, China. Atmos. Environ. 2009, 43, 1954-1961. [CrossRef]

25. Ahmady-Birgani, H.; Ravan, P.; Schlosser, J.S.; Cuevas-Robles, A.; AzadiAghdam, M.; Sorooshian, A. On the chemical nature of wet deposition over a major desiccated lake: Case study for Lake Urmia basin. Atmos. Res. 2020, 234, 104762. [CrossRef]

26. Zeng, J.; Yue, F.-J.; Li, S.-L.; Wang, Z.-J.; Qin, C.-Q.; Wu, Q.-X.; Xu, S. Agriculture driven nitrogen wet deposition in a karst catchment in southwest China. Agric. Ecosyst. Environ. 2020, 294, 106883. [CrossRef]

27. Zeng, J.; Han, G. Rainwater chemistry observation in a karst city: Variations, influence factors, sources and potential environmental effects. Peer J. 2021, 9, e11167. [CrossRef] [PubMed]

28. Han, G.; Liu, C.-Q. Strontium isotope and major ion chemistry of the rainwaters from Guiyang, Guizhou Province, China. Sci. Total Environ. 2006, 364, 165-174. [CrossRef] [PubMed]

29. Zeng, J.; Han, G. Preliminary copper isotope study on particulate matter in Zhujiang River, southwest China: Application for source identification. Ecotoxicol. Environ. Saf. 2020, 198, 110663. [CrossRef]

30. Xiao, H.W.; Xiao, H.Y.; Long, A.M.; Wang, Y.L.; Liu, C.Q. Chemical composition and source apportionment of rainwater at Guiyang, SW China. J. Atmos. Chem. 2013, 70, 269-281. [CrossRef]

31. Zhang, C.-H.; Ma, L.-D. Ambient air quality trends in Guiyang during 2003-2014. J. Environ. Health 2016, 33, 432-434. (In Chinese)

32. Jia, G.; Chen, F. Monthly variations in nitrogen isotopes of ammonium and nitrate in wet deposition at Guangzhou, south China. Atmos. Environ. 2010, 44, 2309-2315. [CrossRef]

33. Yao, X.; Lau, A.P.S.; Fang, M.; Chan, C.K.; Hu, M. Size distributions and formation of ionic species in atmospheric particulate pollutants in Beijing, China: 2-Dicarboxylic acids. Atmos. Environ. 2003, 37, 3001-3007. [CrossRef]

34. Chan, C.K.; Yao, X. Air pollution in mega cities in China. Atmos. Environ. 2008, 42, 1-42. [CrossRef]

35. Brook, J.R.; Wiebe, A.H.; Woodhouse, S.A.; Audette, C.V.; Dann, T.F.; Callaghan, S.; Piechowski, M.; Dabek-Zlotorzynska, E.; Dloughy, J.F. Temporal and spatial relationships in fine particle strong acidity, sulphate, PM1O, and PM2.5 across multiple canadian locations. Atmos. Environ. 1997, 31, 4223-4236. [CrossRef] 
36. Chow, J.C.; Watson, J.G.; Fujita, E.M.; Lu, Z.; Lawson, D.R.; Ashbaugh, L.L. Temporal and spatial variations of PM2.5 and PM10 aerosol in the Southern California air quality study. Atmos. Environ. 1994, 28, 2061-2080. [CrossRef]

37. Gomišček, B.; Hauck, H.; Stopper, S.; Preining, O. Spatial and temporal variations of PM1, PM2.5, PM10 and particle number concentration during the AUPHEP-Project. Atmos. Environ. 2004, 38, 3917-3934. [CrossRef]

38. Ho, K.F.; Lee, S.C.; Chan, C.K.; Yu, J.C.; Chow, J.C.; Yao, X.H. Characterization of chemical species in PM2.5 and PM10 aerosols in Hong Kong. Atmos. Environ. 2003, 37, 31-39. [CrossRef]

39. Vet, R.; Artz, R.S.; Carou, S.; Shaw, M.; Ro, C.-U.; Aas, W.; Baker, A.; Bowersox, V.C.; Dentener, F.; Galy-Lacaux, C.; et al. A global assessment of precipitation chemistry and deposition of sulfur, nitrogen, sea salt, base cations, organic acids, acidity and $\mathrm{pH}$, and phosphorus. Atmos. Environ. 2014, 93, 3-100. [CrossRef]

40. Zeng, J.; Han, G. Rainwater Chemistry Reveals Air Pollution in a Karst Forest: Temporal Variations, Source Apportionment, and Implications for the Forest. Atmosphere 2020, 11, 1315. [CrossRef]

41. Rashki, A.; Rautenbach, C.J.d.; Eriksson, P.G.; Kaskaoutis, D.G.; Gupta, P. Temporal changes of particulate concentration in the ambient air over the city of Zahedan, Iran. Air Qual. Atmos. Health 2013, 6, 123-135. [CrossRef]

42. Ervens, B.; Turpin, B.J.; Weber, R.J. Secondary organic aerosol formation in cloud droplets and aqueous particles (aqSOA): A review of laboratory, field and model studies. Atmos. Chem. Phys. 2011, 11, 11069-11102. [CrossRef]

43. Huang, R.-J.; Zhang, Y.; Bozzetti, C.; Ho, K.-F.; Cao, J.-J.; Han, Y.; Daellenbach, K.R.; Slowik, J.G.; Platt, S.M.; Canonaco, F.; et al. High secondary aerosol contribution to particulate pollution during haze events in China. Nature 2014, 514, 218-222. [CrossRef] [PubMed]

44. Wu, Q.; Han, G. Sulfur isotope and chemical composition of the rainwater at the Three Gorges Reservoir. Atmos. Res. 2015, 155, 130-140. [CrossRef]

45. Szwed, M.; Kozłowski, R.; Żukowski, W. Assessment of Air Quality in the South-Western Part of the Świętokrzyskie Mountains Based on Selected Indicators. Forests 2020, 11, 499. [CrossRef]

46. Zhu, Y.; Zhang, J.; Wang, J.; Chen, W.; Han, Y.; Ye, C.; Li, Y.; Liu, J.; Zeng, L.; Wu, Y.; et al. Distribution and sources of air pollutants in the North China Plain based on on-road mobile measurements. Atmos. Chem. Phys. 2016, 16, 12551-12565. [CrossRef]

47. Zu, T.L.; Zu, Q.; Wang, Y. Numerical-simulation of air pollutant transport and diffusion in a mountainous city. Atmos. Environ. Part Gen. Top. 1992, 26, 2689-2697.

48. Fan, W.; Wu, J.; Li, X.; Yang, F.; Chen, B.; Guo, J. Influences of a Quasi-stationary Front on Particulate Matter in the Low-latitude Plateau Region in China. Aerosol Air Qual. Res. 2021, 21, 200125. [CrossRef]

49. Zeng, J.; Han, G.; Wu, Q.; Tang, Y. Effects of agricultural alkaline substances on reducing the rainwater acidification: Insight from chemical compositions and calcium isotopes in a karst forests area. Agric. Ecosyst. Environ. 2020, 290, 106782. [CrossRef]

50. Xu, P.; Hao, Q.-J.; Ji, D.-S.; Zhang, J.-K.; Liu, Z.-R.; Hu, B.; Wang, Y.-S.; Jiang, C.-S. Observation of Atmospheric Pollutants in the Urban Area of Beibei District, Chongqing. Environ. Sci. 2014, 35, 820-829. (In Chinese)

51. Liang, L.; Wang, Z. Control Models and Spatiotemporal Characteristics of Air Pollution in the Rapidly Developing Urban Agglomerations. Int. J. Environ. Res. Public Health 2021, 18, 6177. [CrossRef] [PubMed]

52. Tang, Y.; Zhang, X.; Xu, J.; Zhao, X.; Ma, Z.; Meng, W. Multi-temporal scale variations of atmospheric pollutants concentrations in rural and urban areas of Beijing. Acta Sci. Circumstantiae 2016, 36, 2783-2793. (In Chinese)

53. Zeng, J.; Yue, F.-J.; Wang, Z.-J.; Wu, Q.; Qin, C.-Q.; Li, S.-L. Quantifying depression trapping effect on rainwater chemical composition during the rainy season in karst agricultural area, southwestern China. Atmos. Environ. 2019, 218, 116998. [CrossRef]

54. Zeng, J.; Yue, F.-J.; Xiao, M.; Wang, Z.J.; Wu, Q.; Qin, C.-Q. Dissolved organic carbon in rainwater from a karst agricultural area of Southwest China: Variations, sources, and wet deposition fluxes. Atmos. Res. 2020, 245, 105140. [CrossRef]

55. Wang, S.; Yu, R.; Shen, H.; Wang, S.; Hu, Q.; Cui, J.; Yan, Y.; Huang, H.; Hu, G. Chemical characteristics, sources, and formation mechanisms of PM2.5 before and during the Spring Festival in a coastal city in Southeast China. Environ. Pollut. 2019, 251, 442-452. [CrossRef]

56. Zhang, M.; Zhang, S.; Bao, Q.; Yang, C.; Qin, Y.; Fu, J.; Chen, W. Temporal Variation and Source Analysis of Carbonaceous Aerosol in Industrial Cities of Northeast China during the Spring Festival: The Case of Changchun. Atmosphere 2020, 11, 991. [CrossRef]

57. Wang, Z.; Zhang, D.; Li, Y.; Feng, P.; Dong, X.; Sun, R.; Pan, L. Analysis of air quality in Beijing City during Spring Festival period of 2014. Acta Sci. Circumstantiae 2015, 35, 371-378. (In Chinese)

58. Yao, L.; Wang, D.; Fu, Q.; Qiao, L.; Wang, H.; Li, L.; Sun, W.; Li, Q.; Wang, L.; Yang, X.; et al. The effects of firework regulation on air quality and public health during the Chinese Spring Festival from 2013 to 2017 in a Chinese megacity. Environ. Int. 2019, 126, 96-106. [CrossRef]

59. Xiao, H.-W.; Xiao, H.-Y.; Wang, Y.-L.; Tang, C.-G.; Liu, X.-Y. Chemical Characteristics of 9 d Continuous Precipitation in a Typical Polluted City: A Case Study of Guiyang, China. Environ. Sci. 2010, 31, 865-870. (In Chinese)

60. Uchiyama, R.; Okochi, H.; Katsumi, N.; Ogata, H. The impact of air pollutants on rainwater chemistry during "urban-induced heavy rainfall" in downtown Tokyo, Japan. J. Geophys. Res. Atmos. 2017, 122, 6502-6519. [CrossRef]

61. Rao, W.; Han, G.; Tan, H.; Jin, K.; Wang, S.; Chen, T. Chemical and Sr isotopic characteristics of rainwater on the Alxa Desert Plateau, North China: Implication for air quality and ion sources. Atmos. Res. 2017, 193, 163-172. [CrossRef]

62. Wei, J.; Huang, W.; Li, Z.; Xue, W.; Peng, Y.; Sun, L.; Cribb, M. Estimating 1-km-resolution PM2.5 concentrations across China using the space-time random forest approach. Remote Sens. Environ. 2019, 231, 111221. [CrossRef] 
63. Ge, B.; Xu, D.; Wild, O.; Yao, X.; Wang, J.; Chen, X.; Tan, Q.; Pan, X.; Wang, Z. Inter-annual variations of wet deposition in Beijing from 2014-2017: Implications of below-cloud scavenging of inorganic aerosols. Atmos. Chem. Phys. 2021, 21,9441-9454. [CrossRef]

64. Ouyang, W.; Guo, B.; Cai, G.; Li, Q.; Han, S.; Liu, B.; Liu, X. The washing effect of precipitation on particulate matter and the pollution dynamics of rainwater in downtown Beijing. Sci. Total Environ. 2015, 505, 306-314. [CrossRef]

65. McMullen, N.; Annesi-Maesano, I.; Renard, J.-B. Impact of Rain Precipitation on Urban Atmospheric Particle Matter Measured at Three Locations in France between 2013 and 2019. Atmosphere 2021, 12, 769. [CrossRef]

66. Silva, M.P.R.; Gonçalves, F.L.T.; Freitas, S.R. Two case studies of sulfate scavenging processes in the Amazon region (Rondônia). Environ. Pollut. 2009, 157, 637-645. [CrossRef] [PubMed]

67. Naimabadi, A.; Shirmardi, M.; Maleki, H.; Teymouri, P.; Goudarzi, G.; Shahsavani, A.; Sorooshian, A.; Babaei, A.A.; Mehrabi, N.; Baneshi, M.M.; et al. On the chemical nature of precipitation in a populated Middle Eastern Region (Ahvaz, Iran) with diverse sources. Ecotoxicol. Environ. Saf. 2018, 163, 558-566. [CrossRef]

68. Arimoto, R.; Duce, R.A.; Savoie, D.L.; Prospero, J.M.; Talbot, R.; Cullen, J.D.; Tomza, U.; Lewis, N.F.; Ray, B.J. Relationships among aerosol constituents from Asia and the North Pacific during PEM-West A. J. Geophys. Res. Atmos. 1996, 101, 2011-2024. [CrossRef]

69. Lü, P.; Han, G.; Wu, Q. Chemical characteristics of rainwater in karst rural areas, Guizhou Province, Southwest China. Acta Geochim. 2017, 36, 572-576. [CrossRef]

70. Keresztesi, Á.; Nita, I.-A.; Birsan, M.-V.; Bodor, Z.; Pernyeszi, T.; Micheu, M.M.; Szép, R. Assessing the variations in the chemical composition of rainwater and air masses using the zonal and meridional index. Atmos. Res. 2020, 237, 104846. [CrossRef] 